\title{
Yüksek Performanslı İş Sistemlerinin Çalışan Performansı Üzerindeki Etkisinde İşe Tutkunluğun Aracılık Rolü Esra DİCC ELMALI ${ }^{1}$ Gülşah GENÇER ÇELIK ${ }^{2}$ Erkan TAŞKIRAN ${ }^{3}$
}

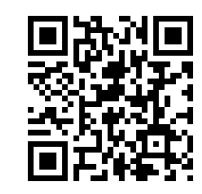

\begin{tabular}{ccc}
\hline Geliş Tarihi/ Received & Kabul Tarihi/ Accepted & Yayın Tarihi/ Published \\
26.01 .2021 & 02.07 .2021 & 15.07 .2021 \\
\hline
\end{tabular}

Citation/Atıf: Dinç Elmall, E., Gençer Celik, G. ve Taşkıran, E., (2021), Yüksek Performanslı Is Sistemlerinin Çalışan Performansı Üzerindeki Etkisinde İşe Tutkunluğun Aracılık Rolü, Atatürk Üniversitesi İktisadi ve İdari Bilimler Dergisi, 35(3): Sayfa: 997-1020, https://doi.org/10.16951/atauniiibd.868897

Öz: İnsan kaynakları uygulamaları ve örgüt stratejisini yenilikçi bir yaklaşım ile bütünleştiren yüksek performanslı iş sistemleri, günümüz iş yaşamında üzerinde önemle durulması gereken bir araç olarak karşımıza çıkmaktadır. Özellikle yüksek performanslı iș sistemlerini uygulayan örgütlerde, yaptığı iș ile kendisini tanımlayan çalıșanların göstereceği performansın örgütsel performansı artıracağı düșünülmektedir. Bu bağlamda ele alınan çalışmanın temel amacı yüksek performanslı iş sistemlerinin çalışan performansı üzerindeki etkisinde işe tutkunluğun aracılık rolünü incelemektir. Çalışmanın alana katkısı, yüksek performanslı iș sistemlerinin bireysel çıktılar üzerindeki etkisinin nedenselliğini açıklayan alt değișkenlerle ilgili çalıșma boşluğunu doldurmaktır. Araștırma, İstanbul'da faaliyet gösteren farklı alanlardaki hizmet işletmelerinde görev yapan 314 çalışan üzerinde anket tekniği yardımıyla gerçekleştirilmiştir. Araştırmada Yüksek Performanslı İş Sistemleri Ölçeği, İşe Tutkunluk Ölçeği, Bağlamsal Performans ve Yaratıcı Performans Ölçekleri olmak üzere dört farklı ölçek kullanılmıștır. Ölçüm aracında 47 ifade bulunmaktadır. Elde edilen verilerin analizi için SPSS ve AMOS programları aracılığıyla, faktör analizi, güvenilirlik analizi ve yapısal eşitlik modellemesinden yararlanılmıştır. Araştırma sonucunda, öne sürülen hipotezlerin desteklendiği görülmüștür. Calıșmanın temel amacı kapsamında araștırma bulguları, yüksek performanslı is sistemlerinin çalışan performansı üzerindeki etkisinde ișe tutkunluğun kısmi aracılık etkisi olduğunu ortaya koymuștur. Anahtar Kelimeler: Yüksek Performanslı İş Sistemleri, Bağlamsal Performans, Yaratıcı Performans, İşe Tutkunluk

\section{The Mediating Role of Work Engagement on the Effect of High Performance Work Systems on}

\section{Employee Performance}

Abstract: High performance work systems, integrating human resource practices and organizational strategy with an innovative perspective, emerge as a tool that needs to be emphasized in today's business environment. Especially it is predicted that organizational performance will increase with the increase of employee performance in organizations implementing high performance work systems. Within this context the main purpose of this research is to measure the mediating role of work engagement on the effect of high performance work systems on employee performance. The main contribution of this study into the field is to fill the gap about the lack of studies related to sub variables explaining the causality of the effect of high performance work systems on individual outcomes. The research was conducted on 314 employees who are working in service businesses having operations in Istanbul via questionnaire technique. Four different scales consisted of High Performance Work Systems Scale, Work Engagement Scale, Contextual Performance and Creative Performance Scales were used in the study. The scale for the study consists 47 statements. In order to analyze the gathered data via SPSS and AMOS statistical programs, factor analysis, reliability analysis and the structural equation modelling were used. As a result of the study, all proposed hypotheses were supported. Within the context of the study's main porpose, findings revealed that work engagement determined as a partial mediator on the effect of high performance work systems on employee performance.

Keywords: High Performance Work Systems, Contextual Performance, Creative Performance, Work Engagement JEL Kodu: M12, M50, J21

${ }^{I}$ Doç. Dr., Marmara Universitesi, İktisadi ve İdari Bilimler Fakültesi, Isşletme Bölümü, https://orcid.org/00000003-0408-0944,edinc@marmara.edu.tr

${ }^{2}$ Dr. Öğr., Üyesi, Beykent Üniversitesi, Meslek Yüksekokulu, Isşletme Yönetimi Bölümü, https://orcid.org/00000001-8610-3673,gulsahg@beykent.edu.tr

${ }^{3}$ Doç. Dr., Düzce Üniversitesi, Akçakoca Turizm İşletmeciliği ve Otelcilik Yüksekokulu, Turizm İşletmeciliği Bölümü, https://orcid.org/0000-0001-9696-9358, erkantaskiran@duzce.edu.tr 
Yüksek Performanslı İş Sistemlerinin Çalışan Performansı Üzerindeki Etkisinde İşe Tutkunluğun Aracıllk Rolü

\section{The Need for the Study}

\section{EXTENDED SUMMARY}

The existing literature related high performance work systems emphasized that the companies adopting high performance work systems have a better organizational and financial performance (Huselid, 1995: 635-672; Huselid ve Becker, 1996: 400-422; Hartog ve Verburg, 2004: 55-78; Shih vd., 2006: 741763; Combs vd., 2006: 501-528; Varma vd., 1999: 26-37). Within this context, high performance work systems can be seen as a main source of gaining competitive advantage in today's work environment (Evans and Davis, 2005: 759). However, most researches about high performance work systems were focused on the effects of high performance work systems on individual outcomes, there are a little known about the studies explaining the causality of these effects. Therefore, the mediating role of different variables such as work engagement, organizational identification are needed to be investigated.

\section{The Main Purpose of the Study}

The main purpose of this study is to investigate the mediating role of work engagement on the effect of high performance work systems on employee performance. Employee performance were analyzed as two sub-dimensions consisted of contextual and creative performance.

Research Questions

Do high performance work systems have a significant effect on contextual and creative performance?

Do high performance work systems have a significant effect on work engagement?

Does work engagement affect contextual performance and creative performance?

Does work engagement mediate the relationship between high performance work systems and contextual performance and creative performance?

\section{Methodology}

The questionnaire technique, one of the quantitative methods, was used to gather the data for this study. The research was conducted on 314 employees who are working in service businesses having operations in Istanbul. High Performance Work Systems Scale, Work Engagement Scale, Contextual Performance and Creative Performance Scales were the scales used in the study. In order to analyze the gathered data via SPSS and AMOS statistical programs, factor analysis, reliability analysis and the structural equation modelling were utilized.

\section{Findings}

As a conclusion, all the hypotheses proposed for the study were supported. Within the context of the study's main purpose, findings revealed that work engagement determined as a partial mediator on the effect of high performance work systems on employee performance. 


\section{Giriş}

Hızla değişen günümüz iş yaşamında, farklılaşan müşteri ve yatırımcı talepleri, değişen ürün yelpazesi, müşteri beklentilere yönelik ürün ve hizmetlerin kişiselleştirilmesi gibi nedenlerden dolayı rekabet güçlü bir şekilde artmaktadır. Örgütlerin bu yeni ortamda rekabet edebilmeleri maliyetlerin azaltılması, ürünler ve süreçlerde yenilikler yapılması, kalite ve üretim süreçlerinin iyileştirilmesi gibi yöntemlerle olabilmektedir. Yeni yönetim yaklaşımları örgütlere bu hedefleri başarmaları için yol gösterici olmaktadır. Bu yeni yönetim yaklaşımları maliyetten çok kaliteye önem vererek rekabet etmeyi tercih etmektedir ve bunu yapabilmek için insan kaynaklarına güvenmektedir (Sturm, 2007: 1). İnsan kaynakları alanında çalışan araştırmacılar ve uygulayıcılar en iyi yetenekleri elde etmek, geliştirmek ve motive etmek üzere, beşeri sermayeyi merkeze alan insan kaynakları sistemleri üzerinde önemle durmaktadır (Posthuma vd., 2013: 1184). Söz konusu yeni yönetim yaklaşımlarında karar verme aşaması çalışanları da kapsamakta ve çalışanların mutluluğunu arttıracak birtakım gelişen yönetim uygulamalarına (örneğin; eğitim ve değerlendirme, kâr paylaşımı ve yüksek ücret sistemleri) odaklanmaktadır. Bu yaklaşım "en iyi uygulama" insan kaynakları yönetimi, "yüksek performanslı iş sistemleri" gibi çeşitli şekillerde kavramsallaştırılmıştır. Terminoloji ne olursa olsun, genel fikir; belli bir insan kaynakları uygulama setinin örgütün gelişmiş performans göstermesini sağlayabileceğidir (Sturm, 2007: 2).

Birçok çalışma, yüksek performanslı iş sistemlerini benimseyen kuruluşların daha iyi örgütsel ve finansal performansa sahip olacağını göstermiştir (Huselid, 1995: 635-672; Huselid ve Becker, 1996: 400-422; Hartog ve Verburg, 2004: 55-78; Shih vd., 2006: 741-763; Combs vd., 2006: 501-528; Varma vd., 1999: 26-37). Elde edilen sonuçlara göre yüksek performanslı iş sistemleri işgücü ve firma verimliliği yanında firmanın finansal performansını da arttırmaktadır. Bu bulgulara göre yüksek performanslı iş sistemleri günümüzde rekabet avantajının potansiyel bir kaynağı olarak görülmektedir (Evans ve Davis, 2005: 759). Bununla birlikte yapılan diğer çalışmalarda (Kehoe ve Wright, 2013: 366-391; Wei vd., 2010; Wang vd., 2011: 1631-1638; Luna-Arocas ve Camps, 2007: 26-46; Berg, 1999: 111-135) yüksek performanslı iş sistemlerinin bireysel çıtılar üzerindeki etkileri üzerinde durulurken; bu etkilerin nedenselliğini açıklayan alt değişkenlerle ilgili sınırlı sayıda çalışma olduğu görülmüştür (Kroon vd., 2009: 509-525; Karatepe, 2013: 132-140; Wu ve Chaturvedi, 2009: 1228-1247). Bu bağlamda yapılan bu çalışmayla, yüksek performanslı iş sistemlerinin çalışanların bağlamsal ve yaratıcı performansı üzerindeki etkisinde işe tutkunluğun aracı rolü incelenmiş ve bu kapsamda yazındaki boşluk doldurulmaya çalışılmıştır.

Bu çerçevede çalışmanın ilk kısmında araştırma konusuna ilişkin yazın ve geliştirilen hipotezler gerekçeleriyle sunulmuştur. İkinci kısımda araştırmanın yöntemi, kullanılan ölçekler, örneklem ve analiz teknikleri çerçevesinde 
Yüksek Performanslı İşS Sistemlerinin Çalışan Performansı Üzerindeki Etkisinde İșe Tutkunluğun Aracıllk Rolü

açıklanmıştır. Son kısımda araştırmanın bulguları ve elde edilen sonuçlar tartışılarak ele alınmıştır.

\section{Teorik Çerçeve ve Hipotezlerin Geliştirilmesi}

Bu başlık altında çalışmanın temel değişkenleri olan yüksek performanslı iş sistemleri, bağlamsal ve yaratıcı performans ile işe tutkunlukla ilgili teorik bilgiler verilerek, ilgili yazın kapsamında geliştirilen araştırma hipotezleri sunulmuştur.

\subsection{Yüksek Performansli İ̧ Sistemleri}

Literatürde yüksek performanslı iş sistemleri ile ilgili birçok tanım bulunmaktadır. Bir tanıma göre yüksek performanslı iş sistemleri işlemsel sorunları çözmeye ve firmanın rekabet stratejisini uygulamaya odaklanan, içten tutarlı ve uyumlu bir insan kaynakları yönetim sistemidir (Armstrong, 2009: 234). Benzer başka bir tanıma göre ise yüksek performanslı iş sistemleri, insan kaynakları uygulamaları arasındaki uyum açısından içsel olarak tutarlı, diğer yandan örgütün stratejisi ile uyum göstermesi açısından da dışsal olarak tutarlı bir sistem olarak değerlendirmektedir. Bu kapsamda kendi kendini yöneten takımlar, merkezileşmemiş karar alma, genişletilmiş eğitim, esnek iş tanımları, açık iletişim ve performansa bağlı ücreti ifade eden bütünleştirici bir sistem olarak yüksek performanslı iş sistemleri, örgütün stratejisi ve bütün diğer fonksiyonları ile uyumlu hareket eden bir araç olarak görülmektedir (Evans ve Davis, 2005: 759).

Yüksek performanslı işletmeleri düşük performanslı işletmelerden ayıran dört önemli özellik bulunmaktadır. Bunlardan ilki insan kaynaklarında ölçümlerin önemidir. İşgücü devri, çalışan başı eğitim saati veya başvurulan pozisyonlara nitelikli aday sayıları önemli bir başarı ölçüsü olarak değerlendirilebilir. Yöneticiler bu ölçümleri kullanarak firmalarının insan kaynakları performanslarını değerlendirebilir ve diğer işletmelerle karşılaştırmalar yapabilir. İkincisi, yüksek performanslı sistemlere sahip olabilmek için yöneticilerin yapması gerekenlerle ilgilidir. Örnek olarak bu tür işletmeler işe alımlarda geçerli testlerden faydalanmakta, boş pozisyonların doldurulmasında iç kaynaklara ağılık vermekte ve işleri kendini yöneten takımlar etrafında organize etmekte ve çalışanlarına yoğun eğitim vermektedirler. Üçüncü olarak yüksek performanslı iş uygulamaları genellikle çalışanların kendilerini yönetmelerine imkan vermektedir. Bu işletmelerde işe alım, eğitim ve diğer insan kaynakları uygulamalarının amacı güçlendirilmiş, öz motivasyonu olan esnek işgücünü teşvik etmektir (Dessler, 2013: 118-119).

\subsection{Yüksek Performanslı Işs Sistemleri ve Çalışan Performansı}

Yüksek performanslı iş sistemleri, çalışanları başkaları tarafından taklit edilmesi güç, sürekli gelişebilen temel rekabet avantajı kaynağı olarak görmektedir ve bu yaklaşıma göre çalışanlar motive edilebilirse yüksek seviyede performans göstereceklerdir. Çalışanlara saygıll, yetenekli ve zeki bireyler olarak 
davranıldığında çalışanlar örgüte daha bağlı olacak, yönetime daha fazla güvenecek ve bu da çalışan performansının artmasını sağlayabilecektir (Zacharatos vd., 2005: 77). Whitener (2001) bu ilişkiyi açıklamak için sosyal değişim bakış açısını önermektedir. Buna göre, çalışanlar insan kaynakları uygulamalarını ve yönetimin güvenilirliğini kurumun kendilerine olan bağl1lığının bir göstergesi olarak gördüğünde, çalışanlar buna uygun tutum ve davranışlarla karşıllk vereceklerdir (Zacharatos vd., 2005: 78).

İlgili yazında iş performansı bazı çalışmalarda tek boyutlu olarak ele alınırken bazı çalışmalarda ise çok boyutlu olarak ele alınmıştır. Örneğin, iş performans1, görev performans1 ve bağlamsal performans (Befort ve Hattrup, 2003: 17) ya da görev performans1, örgütsel vatandaşl1k davranış1 ve üretkenlik karşıtı iş davranışı (Harari vd., 2016: 495) gibi boyutlarla ele alınmıştır. Ancak işin doğasındaki değişimlerle, 'adaptasyon-uyum performansı'; bilgi ekonomisi ve bilgi paylaşımının öneminin artmasıyla birlikte 'bilgi aktarımı' iş performansının önemli boyutları olarak ele alınmıştır. Günümüzde de bireysel yaratıcılık ve inovasyonun önem kazanmasıyla 'yaratıcı performans' önemli bir iş performansı boyutu olarak değerlendirilmeye başlanmıştır (Harari vd., 2016: 495).

Bu çalışmada hizmet işletmeleri için özellikle önemli olduğu düşünülen iş performansının bağlamsal ve yaratıcı performans boyutları ele alınmıştır. Bağlamsal performans organizasyonun kültürüne ve iklimine katkıda bulunan davranışları ifade etmektedir. Bağlama dayalı faaliyetler, işin biçimsel bir parçası olmayan, görevleri başarmak için örgütteki diğer kişilere yardımcı olmak ve bu kişilerle işbirliği yapmak gibi gönüllü faaliyetlerdir (Borman ve Motowidlo, 1997: 100). Yaratıcı performans ise çalışanların işle ilgili görevleri yerine getirirken yarattı̆̆ 1 yeni fikirler ve yeni davranışların miktarını ifade etmektedir (Wang ve Netemeyer, 2004: 806).

Literatürde, yüksek performanslı iş sistemleri ile bireysel iş performansı arasındaki ilişkileri araştıran çalışmaların sonucunda da bu iki değişken arasında pozitif yönlü anlamlı ilişkiler olduğu görülmüştür. Guthrie ve diğerleri (2009: 112-125), yüksek performanslı iş sistemlerinin etkinliğini inceledikleri araştırmaları sonucunda; yüksek performanslı iş sistemlerinin kullanılmasının daha düşük oranda çalışan devamsızlığı ve gönüllü çalışan devri, daha düşük işgücü maliyetleri buna karşılık daha yüksek işgücü verimliliği ile ilişkili olduğu sonucuna ulaşmışlardır. Tabiu ve Nura (2013: 247-260) yüksek performanslı insan kaynakları uygulamalarının çalışan performansını pozitif yönde etkilediği sonucuna ulaşmıştır. Muchhal (2014) endüstriyel bir kurumda gerçekleştirdiği araştırmada insan kaynakları uygulamaları (ücretlendirme, performans değerlendirme süreci ve terfi uygulamaları) ile iş performası arasında bir ilişki olduğu yönünde bulgulara ulaşmıştır. Wickramasinghe ve Liyanage (2013: 6477) Sri Lanka'daki proje tabanlı küresel olarak dağıtılan yazılım geliştirme firmalarında yüksek performanslı iş uygulamalarının iş performansı üzerindeki etkilerini araştırmışlardır. Analizler sonucunda performans değerlendirmesi, 
Yüksek Performanslı İşS Sistemlerinin Çalışan Performansı Üzerindeki Etkisinde İșe Tutkunluğun Aracıllk Rolü

öğrenme ve geliştirme ile karar verme sürecine katılım olmak üzere üç ana yüksek performanslı iş uygulamasının proje tabanlı çalışanların iş performanslarını önemli ölçüde ve olumlu bir şekilde etkilediği görülmüştür. Manzoor (2016: 354-363) tarafından insan kaynakları uygulamalarının (işe alım, eğitim ve katılım) iş performansı üzerindeki etkisinde personeli güçlendirmenin moderatör rolünü belirlemeye yönelik yapılan araştırmada da bahsi geçen insan kaynakları uygulamalarının iş performansı üzerinde pozitif yönlü önemli bir etkiye sahip olduğu görülmüştür. İlgili yazın taraması ve konu ile ilgili yapılan araştırmalar sonucu elde edilen bulgular ışığında ilk araştırma hipotezi şu şekilde oluşturulmuştur.

$\boldsymbol{H}_{1}$ : Yüksek performanslı iş sistemlerinin çalışanların (a) bağlamsal ve

(b) yaratıcı performansları üzerinde pozitif yönlü bir etkisi bulunmaktadır.

\subsection{Yüksek Performanslı Işs Sistemleri ve Işse Tutkunluk}

Çalışanın yaptığı iş ile ilişkisini açıklayan işe tutkunluk herhangi bir bireyin iş ortamında sahip olduğu olumlu bir zihin durumunu ifade etmektedir. İşlerine tutkun bireyler fiziksel, bilişsel ve duygusal olarak yaptıkları işlerle etkili bir bağ kurmakta; aksi durumda ise kişiler fiziksel olarak işlerine daha az bağlanmakta ve iş arkadaşlarına karşı olan duygusal bağları kopmaktadır (Yeh, 2013: 218-219).

İşe tutkunluk literatürde de genel olarak, canlılık, özveri (kendini adama) ve özümseme ile karakterize edilen pozitif, doyurucu ve iş ile ilgili bir zihin durumu olarak ifade edilir. İşe tutkunluk temelde çalışanların işi ne şekilde deneyimledikleri ile ilgili bir kavramdır. Bunlardan işle ilgili deneyimler konusunda enerjik bir şekilde zaman ve çaba sarf etmek canlılık boyutunu tanımlarken; işi önemli ve anlamlı bir uğraş olarak değerlendirmek özveri (kendini adama) boyutunu tanımlamakta; işi ilgi çekici bulma ve yoğun bir konsantrasyon sağlama ise özümseme boyutunu ifade etmektedir (Bakker, vd., 2011: 5).

Combs ve diğerleri (2006: 502)'ye göre teşvik edici ücret, eğitim, çalışan katılımı, işe alma ve esnek çalışma düzenlemeleri gibi uygulamaları içeren yüksek performanslı iş sistemleri çalışanların bilgi, beceri ve yeteneklerini artırmaktadır. Bunun sonucunda güçlendirilmiş çalışanların, söz konusu bilgi, beceri ve yeteneklerini örgütün gelişimi için kullanmaları ve bu sayede kendi motivasyonlarını artırmaları söz konusudur. Diğer taraftan, insan kaynakları uygulamaları çalışanların iş hedeflerine etkili bir şekilde ulaşmalarına yardımcı olabilmekte, zaman ve enerji gibi kaynaklarını daha az kullanmalarını sağlamakta ve bu şekilde iş talepleri de azalmaktadır. Çalışanlar iş hedeflerine ulaşabildiğinde, işe tutkunluğu karakterize eden, enerjik, adanmış ve işte mutlu olma gibi işlerine karşı olumlu bir tutum içinde olabilmektedirler (Suan ve Nasurdin, 2014: 348).

İlgili yazında insan kaynakları uygulamalarının işe tutkunluk üzerindeki etkisini araştıran çeşitli çalışmalara rastlamak mümkündür. Alzyoud (2018: 251) 
üretim işletmelerinde görev alan 151 çalışan üzerinde gerçekleştirdikleri araştırmada insan kaynakları uygulamalarının işe tutkunluk üzerinde etkili olduğu sonucuna ulaşmıştır. Suan ve Nasurdin (2014: 345) tarafindan gerçekleştirilen araştırmada insan kaynakları uygulamalarının hizmet eğitimi ve performans değerlendirme boyutlarının işe tutkunluk üzerinde pozitif yönlü ve önemli etkileri olduğuna ilişkin bulgulara ulaşılmıştır. Karatepe ve Olugbade (2016: 2350) gerçekleştirdiği araştırmada seçici işe alma, iş güvencesi, takım çalışması ve kariyer firsatları olarak belirlenen yüksek performanslı iş pratiklerinin işe tutkunluk üzerinde pozitif yönde etkili olduğu sonucuna ulaşmışırı. İlgili yazın taraması ve konu ile ilgili yapılan araştırmalar sonucu elde edilen bulgular 1şı̆̆ında ilk araştırma hipotezi şu şekilde oluşturulmuştur.

$\boldsymbol{H}_{2}$ : Yüksek performanslı iş sistemlerinin çalışanların işe tutkun olmalarında pozitif yönlü bir etkisi bulunmaktadır.

\subsection{Yüksek Performanslı Işs Sistemleri ve İşe Tutkunluk}

İş motivasyonu teorisi, motivasyonun davranıştan önce geldiğini belirtmektedir. İşe tutkunluk motivasyonel bir yapı olarak iş performansının öncülü olarak ele alınabilir. Çünkü çalışanları iş rolleri ile ilgili davranışlarını iyi bir şekilde yapmaya motive edebilir. İşe tutkunluk düzeyi yüksek çalışanlar görevlerini daha fazla enerji ve uzun süreli bir yoğunlaşma ile yerine getirebileceklerinden, bu kişilerin daha yüksek performans sergilemeleri de kuvvetle muhtemel olarak gerçekleşecektir (Song vd., 2018: 255).

İlgili yazında yapılan birçok araştırmada işe tutkunluğun iş performansı üzerinde pozitif yönlü bir etkisi olduğu görülmüştür. Bakker ve Bal (2010: 189), öğretmenler üzerinde gerçekleştirdikleri çalışmada işe tutkunluk ile iş performansı arasında pozitif bir ilişki olduğu sonucuna ulaşılmışlardır. Bakker ve diğerleri (2012: 555) yaptıkları araştırma sonucunda işe tutkunluğun görev performans1 ve bağlamsal performansla pozitif yönlü bir ilişki içerisinde olduğu saptamışlardır. Song ve diğerleri (2018: 249) ise işe tutkunlukla iş performansı arasındaki ilişkiyi inceledikleri araştırmalarında, söz konusu değişkenler arasında istatistiksel olarak anlamlı bir ilişki olduğu sonucuna ulaşılmışlardır. İlgili literatür taraması ve konu ile ilgili yapılan araştırmalar sonucu elde edilen bulgular 1şığında ikinci araştırma hipotezi aşağıdaki şekilde oluşturulmuştur.

$\boldsymbol{H}_{3}$ : Çalışanların işe tutkun olmalarının (a) bağlamsal ve (b) yaratıcı performanslarl üzerinde pozitif yönlü bir etkisi bulunmaktadır.

\section{5. İşe Tutkunluğun Aracıllk Rolü}

İşe tutkunluk ve olumlu iş sonuçları, çalışanların bilişsel, duygusal ve fiziksel kaynaklarını istekli ve yoğunlaşmış bir şekilde iş rolleri için adamalarını sağlamaktadır. Bu şekilde çalışanlar görev yaptıkları örgütlerinin kendileri için sunduğu faydalara ilişkin bir anlamda geri ödeme yapmaktadırlar. Çalışanlar eğitim, güçlendirme ve ödüller ile belirtilen yüksek performanslı iş sistemlerine sahip olduğunda da organizasyona işe tutkunluk düzeyleri vasıtasıyla bir geri ödeme yapmaktadırlar. Çalışanlar, yüksek performanslı iş sistemlerinin 
Yüksek Performanslı İş Sistemlerinin Çalışan Performansı Üzerindeki Etkisinde İşe Tutkunluğun Aracıllk Rolü

kullanılabilirliğinin, yönetimin organizasyonel misyonla tutarlı hizmet mükemmelliğine olan bağlılığından kaynaklandığına inanırlarsa, işlerine daha fazla tutkunluk hissedebilmekte ve hizmet sunum sürecine daha fazla katkıda bulunabilmekedir. Buna ek olarak, yüksek performanslı iş sistemleri işveren ve çalışanlar arasındaki sosyal değişimin kalitesini artırmaktadır. Kısacası, yüksek performanslı iş sistemlerinin var olduğu bir iş çevresi oluşturulduğunda tutkunluğu artan çalışanlar daha fazla güvenilir görünmekte ve işverenleriyle daha yüksek kaliteli ilişkiler kurmakta ve daha iyi performans sonuçları göstermektedir (Karatepe, 2013: 133).

Yazında olumlu iş tutumlarının işle ilgili sonuçlar üzerindeki etkisinde işe tutkunluğun aracı rolünü inceleyen çeşitli çalışmalara rastlamak mümkündür. Yalabik ve diğerleri (2013: 2799) tarafından duygusal bağlilık, iş tatmini, iş performansı ve işten ayrılma niyeti arasındaki ilişkide işe tutkunluğun aracı rolünün araştırıldığı çalışmada duygusal bağl11ıkla iş performansı ve işten ayrılma niyeti arasındaki ilişkide işe tutkunluğun aracı rol oynadığ 1 ayrıca iş tatminin iş performansı arasındaki ilişkiye aracılık ederken iş tatminin işten ayrılma niyeti arasındaki ilişkiye ise kısmi olarak aracılık etiği sonucuna ulaşılmıştır. Li ve diğerleri (2012: 1059) tarafindan yapılan bir araştırmada da lider-üye etkileşiminin iş performansı üzerindeki etkisinde işe tutkunluğun aracı rolü olduğu görülmüştür.

Karatepe (2013: 132) yüksek performanslı iş pratiklerinin iş performansı ve ekstra rol müşteri hizmetleri üzerindeki etkisinde işe tutkunluğun aracı rolünü incelemiştir. Araştırma sonucunda işe tutkunluğun yüksek performanslı iş pratiklerinin iş performansı ve ekstra rol müşteri hizmetleri üzerindeki etkisinde tam olarak aracılık etkisi olduğu görülmüştür.

Karatepe ve Olugbade (2016: 2350) seçici işe alma, iş güvencesi, takım çalışması ve kariyer firsatları olarak belirlenen yüksek performanslı iş pratiklerinin yokluk niyeti, hizmet iyileştirme ve yaratıcı performans üzerindeki etkisinde işe tutkunluğun aracı rolünü incelemiştir. Araştırma sonucunda seçici işe alma, iş güvencesi, takım çalışması ve kariyer firsatlarının aynı anda uygulanmasının işe tutkunluğu arttırdığı ve bunun da yokluk niyetini azalttığı, hizmet iyileştirme ve yaratıcı performansı $\operatorname{arttırdığı~sonucuna~ulaşılmıştır.~İlgili~}$ literatür taraması ve konu ile ilgili yapılan araştırmalar sonucu elde edilen bulgular ışı̆̆ında üçüncü araştırma hipotezi şu şekilde oluşturulmuştur:

$\boldsymbol{H}_{4}$ : Yüksek performanslı iş sistemlerinin çalışanların (a) bağlamsal ve (b) yaratıcı performansları üzerindeki etkisinde işe tutkun olmaları aracılık rolü üstlenmektedir. 


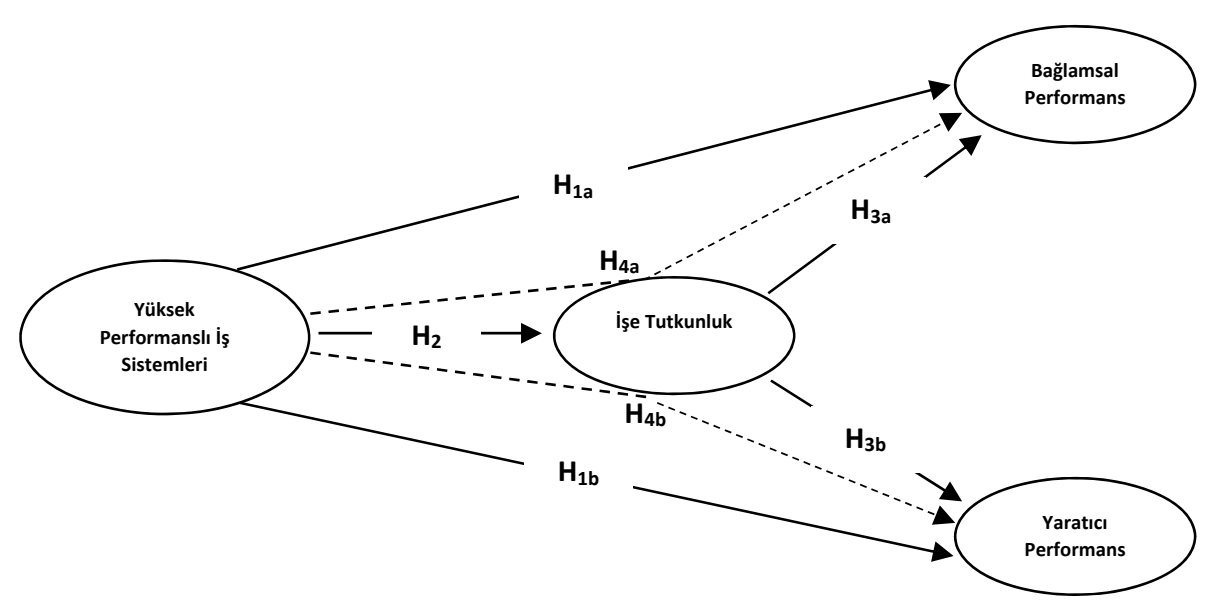

Şekil 1: Araştırma İçin Önerilen Model

Geliştirilen hipotezler çerçevesinde araştırmanın modeli yukarıda gösterilmiştir. Bu kapsamda öncelikle Karatepe (2013: 132-140) çalışmasından esinlenerek oluşturulan modelde yüksek performanslı iş sistemlerinin çalışanların işe tutkunlukları üzerindeki pozitif etkisi; işe tutkunluğun çalışanların (a) bağlamsal ve (b) yaratıcı performansları üzerindeki pozitif etkisi ve son olarak da yüksek performanslı iş sistemlerinin çalışan performansı üzerindeki etkisinde çalışanların işe tutkun olmalarının aracılık rolü oluşturulmuştur.

\section{Yöntem}

$\mathrm{Bu}$ çalışma yüksek performanslı iş sistemlerinin çalışanların bağlamsal ve yaratıcı performansları üzerindeki etkisinde işe tutkunluğun aracılık rolü olup olmadığını belirlemek üzere yapılmıştır. Araştırmada nicel araştırma yöntemlerinden anket tekniği kullanılmıştır. Söz konusu anket formu dört bölümden oluşmaktadır. Birinci bölümde yüksek performanslı iş sistemlerini ölçmek üzere Patel ve diğerleri (2013: 1420-1442)'nin çalışmalarında kullandıkları ve 27 sorudan oluşan Yüksek Performanslı İş Sistemleri Ölçeği kullanılmıştır. Ölçek yüksek performanslı iş sistemlerini kararlara katılım, kariyer planlama, eğitim, işe alma, iş analizi, performans değerleme, iş güvenliği ve ödüllendirme olmak üzere sekiz boyut altında değerlendirmeye imkan vermektedir. Anketin ikinci bölümünde işe tutkunluk tutumunu ölçmek üzere Schaufeli, ve diğerleri (2002: 481-494; 2006: 701-716) tarafindan geliştirilen ve Jung ve Yoon (2016: 59-68)'nun çalışmalarında kullandığı beş soruluk ve tek boyuttan oluşan İşe Tutkunluk Ölçeği kullanılmıştır. Üçüncü bölümde çalışanların bağlamsal performanslarını ölçmek üzere Zoghbi-Manrique-de-Lara ve Ting-Ding (2017: 77-93) çalışmasından yararlanılmışıı. Sekiz sorudan oluşan bağlamsal performans ölçeği tek boyut ile ölçümlenmektedir. Son olarak dördüncü bölümde ise çalışanların yaratıcılık performanslarını ölçmek üzere Wang ve Netemeyer (2004: 805-812) çalışmasındaki yedi soruluk ve tek boyuttan oluşan Yaratıcı Performans Ölçeğinden yararlanılmıştır. Katılımcıların ölçekte 
Yüksek Performanslı İş Sistemlerinin Çalışan Performansı Üzerindeki Etkisinde İşe Tutkunluğun Aracıllk Rolü

bulunan ifadeleri (1) Kesinlikle Katılmıorum ile (5) Kesinlikle Katıliyorum arasında 5'li Likert üzerinden cevaplandırmaları istenmiştir. Araştırma İstanbul ilinde faaliyet gösteren ve hizmet sektörünün bankacılık, turizm, sigortacılık gibi farklı işkollarında görev yapan 314 çalışan üzerinde gerçekleştirilmiştir. İhtiyaç duyulan büyüklükteki örnekleme en kolay ve ulaşılabilir deneklerden erişebilme kolaylığı sağlaması bakımından (Gürbüz ve Şahin, 2016: 134), tesadüfi olmayan örnekleme yöntemlerinden kolayda örneklem yöntemi tercih edilmiştir. Ulaşılan katılımcılara ilişkin demografik özellikler aşağıdaki Tablo 1'de sunulmuştur.

Tablo 1: Katılımcıların Demografik Özellikleri $(n=314)$

\begin{tabular}{|c|c|c|c|c|c|c|c|}
\hline & & f & $\%$ & & & f & $\%$ \\
\hline Cinsiyet & & & & $\begin{array}{l}\text { Mesleki } \\
\text { kıdem }\end{array}$ & & & \\
\hline \multirow{6}{*}{ Yaş } & Kadın & 189 & 60,2 & & 1 y1ldan az & 29 & 9,2 \\
\hline & Erkek & 125 & 39,8 & & $1-5$ yıl arası & 171 & 54,5 \\
\hline & & & & & $6-10$ y1l aras1 & 68 & 21,7 \\
\hline & $18-25$ aras1 & 68 & 21,7 & & $11-15$ y1l aras1 & 24 & 7,6 \\
\hline & $26-35$ aras1 & 202 & 64,3 & & 16 y1l ve üstü & 22 & 7,0 \\
\hline & $36-45$ aras1 & 44 & 14,0 & $\begin{array}{l}\text { Mevcut işy. } \\
\text { kıdem }\end{array}$ & $\begin{array}{l}1 \text { yıldan az } \\
1-5 \text { y1l aras1 }\end{array}$ & $\begin{array}{c}40 \\
177\end{array}$ & $\begin{array}{l}12,7 \\
56,4\end{array}$ \\
\hline \multirow[t]{8}{*}{$\begin{array}{l}\text { Eğitim } \\
\text { düzeyi }\end{array}$} & & & & & $6-10$ y1l aras1 & 58 & 18,5 \\
\hline & Ortaöğretim & 3 & 1,0 & & $11-15$ y1l aras1 & 25 & 8,0 \\
\hline & Lise & 51 & 16,2 & & 16 y1l ve üstü & 14 & 4,5 \\
\hline & Lisans & 232 & 73,9 & Görev tanımı & & & \\
\hline & Yüksek lisans & 28 & 8,9 & & Takım üyesi & 217 & 69,1 \\
\hline & Doktora & - & - & & Takım yöneticisi & 54 & 17,2 \\
\hline & & & & & $\begin{array}{l}\text { Orta kademe } \\
\text { yönetici }\end{array}$ & 40 & 12,7 \\
\hline & & & & & $\begin{array}{l}\text { Üst kademe } \\
\text { yönetici }\end{array}$ & 3 & 1,0 \\
\hline
\end{tabular}

Katılımcıların demografik özelliklerine bakıldığında çoğunluğunun $(\% 60,2)$ kadın ve 26-35 yaş aralığında $(\% 64,3)$ olduğu görülmektedir. Eğitim düzeyi olarak lisans mezunlarının $(\% 73,9)$ çoğunluğu oluşturduğu belirlenmiştir. Mesleki kıdem açısından çoğunluğun \%54,5 ile 1-5 yıl arası kıdeme sahip olduğu tespit edilmişken, şu anki mevcut işyerlerinde çalışma süresi olarak ise yine 1-5 yıl arası çalışanların çoğunlukta $(\% 56,4)$ olduğu saptanmıştır. Son olarak grev tanımları açısından katılımcıların \%69,1'lik bir yüzde ile büyük çoğunluğunun takım üyesi görev tanımında olduğu görülmektedir.

Araştırmanın ana veri toplama işleminden önce 20 kişilik bir katılımcı grubu üzerinde pilot bir çalışma gerçekleştirilerek, anket formundaki soruların ifade edilişi ve anlaşılabilirliği açısından bir sorun bulunup bulunmadığ gözlenmiştir. Yapılan pilot çalışma sonucunda tercümeden kaynaklı bazı kelime seçimlerinin yerinde olmadığ 1 ve sorularda anlam kaybı yarattığ 1 tespit edilmiştir. Örneğin yüksek performanslı iş sistemleri ölçeğindeki "kadrolama" kelimesi 
yerine "işe alım" kelimesi tercih edilmiştir. Bu kapsamda ifadeler yeniden gözden geçirilerek ölçek son haline getirilmiştir. Pilot çalışma sonucu elde edilen verilere güvenilirlik testi uygulanmış ve sonucun $(\alpha=0,91)$ yüksek olduğu saptanmıştır.

Verilerin analizinde SPSS ve AMOS istatistik programlarından yararlanılmıştır. $\mathrm{Bu}$ çerçevede tanımlayıcı istatistikler kapsamında frekans ve yüzde analizi, ölçeklerin yapı geçerliliğini belirlemek üzere faktör analizi (Sipahi vd., 2008: 78-89) uygulanmıştır. Ölçeklerin iç tutarlılığını tespit etmek için güvenilirlik analizleri kullanılmıştır. Son olarak belirlenen hipotezleri test etmek için yapısal eşitlik modellemesinden yararlanılmıştır (Karagöz, 2016: 964-976).

\section{Bulgular}

$\mathrm{Bu}$ bölümde araştırmanın temel amacını gerçekleştirmek üzere toplanan verilerin analizleri sonucunda elde edilen bulgular sunulmuştur.

\subsection{Faktör Analizi}

Araştırmada kullanılan tüm ölçekler ayrı ayrı keşifsel faktör analizi kapsamında analiz edilmiştir. Bu kapsamda öncelikle 27 ifadeden oluşan Yüksek Performanslı İş Sistemleri ölçeği analiz edilmiş ve ilgili ölçeğin KMO örneklem yeterliliği değeri 0,927; Barlett küresellik testi sonucu ise $\left(\chi^{2}=4483,345\right.$; $\mathrm{p}<0,001)$ anlamlı çıkmıştır. Bu sonuçlardan hareketle ilgili ölçeğe faktör analizi yapılmasının uygun olduğu görülmüş̧ür. Keşifsel faktör analizi yapılırken, ilgili ifadelerin anti-image değerlerinin ve faktör yüklerinin 0,50 'den yüksek olması izlenmiş ve her bir faktörde tek bir ifade olmamasına (Sipahi vd. 2008: 78-89) dikkat edilmiştir. Buna göre ilk adımda anti-image değeri 0,50'nin altında olan 5 nolu ifade analizden çıkarılmış ve sonrasında yapılan ikinci adımda faktör yükleri 0,50'nin altında olan 17, 24 ve 25 nolu ifadeler analiz dışı bırakılmıştır. Yapılan son adımdaki faktör analizi sonucunda Yüksek Performanslı İs Sistemleri Ölçeği beş boyut altında toplanmıştır. Söz konusu ölçeğin orijinal yapısındaki sekiz boyutlu yerine belirlenen beş boyutlu hali aşağıdaki Tablo 2'de gösterilmiş̧ir.

Tablo 2: Yüksek Performanslı İs Sistemleri (YPIS) Ölçeğine Ait Keşifsel Faktör Analizi ve Güvenilirlik Analizi Sonuçları

\begin{tabular}{|c|c|c|c|c|}
\hline Faktör Adı & İfadeler & Faktör Yükleri & $\begin{array}{c}\text { Faktör } \\
\text { Açıklayıcılığı (\%) }\end{array}$ & $\begin{array}{c}\text { Cronbach } \\
\text { Alfa Değeri }\end{array}$ \\
\hline İșe alım - Perf. & YPIS27 & .799 & 18,037 & 0.894 \\
\hline \multirow[t]{6}{*}{ Değ. - Ödül } & YPIS26 & .719 & & \\
\hline & YPİS23 & .656 & & \\
\hline & YPİS16 & .605 & & \\
\hline & YPİS22 & .598 & & \\
\hline & YPİS14 & .564 & & \\
\hline & YPİS15 & .531 & & \\
\hline Kararlara & YPİS2 & .802 & 17,547 & 0,882 \\
\hline \multirow[t]{4}{*}{ Katılım } & YPİS1 & .793 & & \\
\hline & YPİS3 & .704 & & \\
\hline & YPIS4 & .694 & & \\
\hline & YPİS8 & .565 & & \\
\hline
\end{tabular}


Yüksek Performanslı İş Sistemlerinin Çalışan Performansı Üzerindeki Etkisinde İşe Tutkunluğun Aracılık Rolü

Tablo 2 Devamı: Yüksek Performanslı İş Sistemleri (YPIS) Ölçeğine Ait Keşifsel Faktör Analizi ve Güvenilirlik Analizi Sonuçları

\begin{tabular}{|c|c|c|c|c|}
\hline Eğitim & $\begin{array}{l}\text { YPIS11 } \\
\text { YPIS10 } \\
\text { YPIS12 } \\
\text { YPIS13 } \\
\text { YPIS9 }\end{array}$ & $\begin{array}{l}.769 \\
.707 \\
.641 \\
.561 \\
.546\end{array}$ & 14,442 & 0,795 \\
\hline İş Tanımı & $\begin{array}{l}\text { YPİS20 } \\
\text { YPISS19 } \\
\text { YPİS18 } \\
\text { YPISS21 }\end{array}$ & $\begin{array}{r}.779 \\
.746 \\
.702 \\
.565 \\
\end{array}$ & 11,479 & 0,861 \\
\hline $\begin{array}{l}\text { Kariyer } \\
\text { Planlama }\end{array}$ & $\begin{array}{l}\text { YPİS6 } \\
\text { YPİS7 }\end{array}$ & $\begin{array}{r}.864 \\
.591 \\
\end{array}$ & 5,565 & 0,687 \\
\hline \multirow[t]{3}{*}{ TOPLAM } & & \multicolumn{3}{|c|}{67,069} \\
\hline & & KMO örn & $\begin{array}{r}\text { eterliliği testi } \\
\text { ki-kare }\end{array}$ & $\begin{array}{l}0,927 \\
4483,345\end{array}$ \\
\hline & & Barlett K & $\begin{array}{rr}\text { testi } & \begin{array}{r}\text { df } \\
\text { sig }\end{array} \\
\end{array}$ & $\begin{array}{l}253 \\
0,000 \\
\end{array}$ \\
\hline
\end{tabular}

Buna göre, orijinali sekiz boyutlu olan Yüksek Performanslı İs Sistemleri ölçeğinden iş güvenliği boyutu analiz dışı kalmıştır. İşe alım, performans değerleme ve ödüllendirme boyutları ise tek bir boyut altında toplanmıştır. Diğer boyutlar olan kararlara katılım, eğitim, iş tanımı ve kariyer planlama ise ayrı ayrı tek faktörlü olarak yapılanmıştır. Araştırmada kullanılan diğer ölçekler için de keşifsel faktör analizi uygulanmış ve elde edilen Kaiser-Meyer-Olkin (KMO) örneklem yeterliliği ve Barlett Küresellik testi ile güvenilirlik analizi sonuçları aşağıdaki Tablo 3'de sunulmuştur.

Tablo 3: İşe Tutkunluk, Bağlamsal Performans ve Yaratıcı Performans Ölçeklerine Ait KMO ve Barlett Küresellik Testi ile Güvenilirlik Analizi Sonuçları

\begin{tabular}{lccc}
\hline Ölçek Adı & $\begin{array}{l}\text { Keiser-Meyer- } \\
\text { Olkin İstatistiği }\end{array}$ & $\begin{array}{c}\text { Barlett Küresellik } \\
\text { Testi Sonucu }\end{array}$ & $\begin{array}{c}\text { Cronbach Alfa } \\
\text { Değeri }\end{array}$ \\
\hline $\begin{array}{l}\text { İşe Tutkunluk } \\
\text { Ölçeği }\end{array}$ & 0,769 & $\chi^{2}=720,495 ; \mathrm{p}<0,001$ & 0,828 \\
\hline $\begin{array}{l}\text { Bağlamsal } \\
\text { Performans Ölçeği }\end{array}$ & 0,896 & $\chi^{2}=1524,951 ; \mathrm{p}<0,001$ & 0,911 \\
\hline $\begin{array}{l}\text { Yaratıcı } \\
\text { Performans Ölçeği }\end{array}$ & 0,891 & $\chi^{2}=1472,831 ; \mathrm{p}<0,001$ & 0,914 \\
\hline
\end{tabular}

Tablo 3'de görüldüğü üzere söz konusu üç ölçeğin de hem örneklem faktör analizi yapmaya uygun hem de değişkenler arasında faktör analizi yapmaya yeterli düzeyde ilişki olduğu tespit edilmiştir. Elde edilen bu sonuçlar kapsamında yapılan faktör analizi sonucunda İşe Tutkunluk Ölçeği, Bağlamsal Performans Ölçeği ve Yaratıcı Performans Ölçeklerinin her birinin ayrı ayrı tek faktörde toplandığı saptanmıştır. Diğer taraftan tüm ölçeklerin güvenilirlik testi sonuçları da 0,70 'in üzerinde bulunmasından dolayı (Saruhan ve Özdemirci, 2011: 171), araştırmada kullanılan ölçeklerin güvenilir olduğu söylenebilir. 
Tablo 4: Ölçeklere İlişkin Doğrulayıcı Faktör Analizi Sonucu Elde Edilen

\begin{tabular}{lcccc}
\multicolumn{5}{c}{ Uyum Değerleri } \\
\hline Ölçek Adı & $\mathbf{X}^{\mathbf{2}}$ / df & GFI & CFI & RMSEA \\
\hline YİPS Ölçeği & 2,426 & 0,984 & 0,990 & 0,067 \\
İşe Tutkunluk Ölçeği & 2,523 & 0,988 & 0,991 & 0,070 \\
Bağlamsal Perf. Ölçeği & 5,010 & 0,930 & 0,944 & 0,125 \\
Yaratıcı Perf. Ölçeği & 3,996 & 0,974 & 0,984 & 0,098 \\
İyi Uyum Değerleri* & $\leq \mathbf{3}$ & $\mathbf{0 0 , 9 0}$ & $\geq \mathbf{0 , 9 7}$ & $\leq \mathbf{0 , 0 5}$ \\
Kabul Edil. Uyum & $\leq \mathbf{4 - 5}$ & $\mathbf{0 , 8 9}-\mathbf{0 , 8 5}$ & $\mathbf{2 0 , 9 5}$ & $\mathbf{0 , 0 6}-\mathbf{0 , 0 8}$ \\
Değerleri* & &
\end{tabular}

$\mathrm{X}^{2}=$ Chi-Square (Ki-Kare); df=Degree of Freedom (Serbestlik Derecesi); GFI= Goodness of Fit Index (İyilik Uyum İndeksi); CFI= Comparative Fit Index (Karşılaştırmalı Uyum İndeksi); RMSEA= Root Mean Square Error of Approxmation (Yaklaşık Hataların Ortalama Karakökü)

Kaynak: Meydan, C.H. ve Şeşen, H. (2011). Yapısal Eşitlik Modellemesi Amos Uygulamaları, Ankara: Detay Yayıncılık, s.37.

Faktör analizinin bir sonraki adımında, keşifsel faktör analizi sonucu elde edilen sonuçlara yönelik ölçeklerin geçerliliğini ölçmek üzere doğrulayıcı faktör analizi uygulanmıştır. Bu kapsamda SPSS programından AMOS programına aktarılan veriler üzerinden; işe tutkunluk, bağlamsal performans ve yaratıcı performans ölçekleri için tek faktörlü doğrulayıcı faktör analizi, yüksek performanslı iş sistemleri için ise çok faktörlü doğrulayıcı faktör analizi yapılmıştır. Yapılan analizler sonucu ölçeklerin uyum değerleri kabul edilebilir uyum değerleri sınırında olmadığı tespit edildiği üzere AMOS programının önerdiği modifikasyonlar uygulanmıştır. Yapılan modifikasyonlar sonucu yüksek performanslı is sistemleri ölçeğinden kariyer planlama boyutunu oluşturan sorular dahil 3 ifade çıkarılmış ve ölçek dört faktörlü bir yapı halinde kabul edilmiştir. Diğer ölçeklerden bağlamsal performans ölçeğinden bir ifade ve yaratıcı performans ölçeğinden ise iki ifade çıkartılmıştır. Sonuç olarak araştırmada kullanılan ölçeklerin uyum değerleri kabul edilebilir sınırlar içinde olduğu üzere, yüksek performanslı iş sistemleri işe alım-performansödüllendirme, kararlara katılım, iş analizi ve eğitim-geliştirme olmak üzere dört faktörlü, diğer ölçek olan işe tutkunluk, bağlamsal performans ve yaratıcı performans ise tek faktör yapısında doğrulanmıştır. Tablo 4'de doğrulayıcı faktör analizi sonuçları sunulmuştur.

\subsection{Korelasyon Analizi}

Araştırmanın değişkenleri arasındaki ilişkiyi tespit etmek üzere yapılan korelasyon analizi sonuçları aşağıdaki Tablo 5'de gösterilmiştir. 
Yüksek Performanslı İş Sistemlerinin Çalışan Performansı Üzerindeki Etkisinde İşe Tutkunluğun Aracıllk Rolü

Tablo 5: Korelasyon Analizi Sonuçları

\begin{tabular}{lccccccccc}
\hline \multicolumn{1}{c}{ Değişkenler } & Ort. & s.s. & $\mathbf{1}$ & $\mathbf{2}$ & $\mathbf{3}$ & $\mathbf{4}$ & $\mathbf{5}$ & $\mathbf{6}$ & $\mathbf{7}$ \\
\hline 1. Kararlara & 3,38 & 0,99 & - & & & & & & \\
Katılım & & & & & & & & \\
2. Eğitim- & 3,37 & 0,89 &, $56^{* *}$ & - & & & & \\
Geliştirme & & & & & & & & \\
3. İs Analizi & 3,66 & 0,91 &, $65^{* *}$ &, $54^{* *}$ & - & & & \\
4. İse A.-Perf- & 3,27 & 1,00 &, $71^{* *}$ &, $61^{* *}$ &, $74^{* *}$ & - & & \\
Ödül. & & & & & & & & \\
5. İşe Tutkunluk & 3,63 & 0,87 &, $42^{* *}$ &, $33^{* *}$ &, $41^{* *}$ &, $40^{* *}$ & - & & \\
6. Bağlamsal & 3,84 & 0,78 &, $49^{* *}$ &, $44^{* *}$ &, $51^{* *}$ &, $52^{* *}$ &, $70^{* *}$ & - & \\
Per. & & & & & & & & & \\
7. Yaratıcı Perf. & 4,00 & 0,70 &, $33^{* *}$ &, $32^{* *}$ &, $34^{* *}$ &, $39^{* *}$ &, $62^{* *}$ &, $64^{* *}$ & - \\
\hline
\end{tabular}

Tablo 5'deki verilere göre, yüksek performanslı iş sistemleri alt boyutları ile tüm diğer değişkenler arasında anlamlı ilişkiler söz konusudur. Bu kapsamda, yüksek performanslı iş sistemleri boyutlarından kararlara katılım boyutu ile işe tutkunluk $(\mathrm{r}=, 42)$, bağlamsal performans $(\mathrm{r}=, 49)$ ve yaratıcı performans arasında $(\mathrm{r}=, 33)$ pozitif yönlü ve orta düzeyde ilişki; eğitim-geliştirme ile ile ișe tutkunluk $(\mathrm{r}=, 33)$, bağlamsal performans $(\mathrm{r}=, 44)$ ve yaratıcı performans arasında $(\mathrm{r}=, 32)$ pozitif yönlü ve orta düzeyde ilişki; iş analizi boyutu ile işe tutkunluk $(\mathrm{r}=, 41)$, bağlamsal performans $(\mathrm{r}=, 51)$ ve yaratıc1 performans arasında $(\mathrm{r}=, 34)$ pozitif yönlü ve orta düzeyde ilişki ve son olarak işe alım-performans-ödüllendirme boyutu ile işe tutkunluk $(\mathrm{r}=, 40)$, bağlamsal performans $(\mathrm{r}=, 52)$ ve yaratıcı performans arasında $(\mathrm{r}=, 39)$ pozitif yönlü ve orta düzeyde ilişkiler saptanmıştır. İse tutkunluk ile bağlamsal performans $(\mathrm{r}=, 70)$ ve yaratıcı performans $(\mathrm{r}=, 62)$ arasında ise yine pozitif yönlü ve güçlü ilişki olduğu tespit edilmiştir.

\subsection{Yapısal Eşitlik Modellemesi ile Hipotez ve Aracılık Etki Testi}

Araştırma kapsamında belirlenen hipotezleri test etmek üzere AMOS programından yararlanılmıştır. $\mathrm{H}_{1}$ hipotezini test etmek amacıyla oluşturulan yapısal eşitlik modeli Şekil 2'de gösterilmiştir. Söz konusu modelin uyum değerleri $\quad \mathrm{X}^{2} / \mathrm{df}=2,917 ; \quad \mathrm{GFI}=0,803 ; \quad \mathrm{CFI}=0,869 ; \quad \mathrm{RMSEA}=0,078 \quad$ olarak gerçekleşmiştir. 


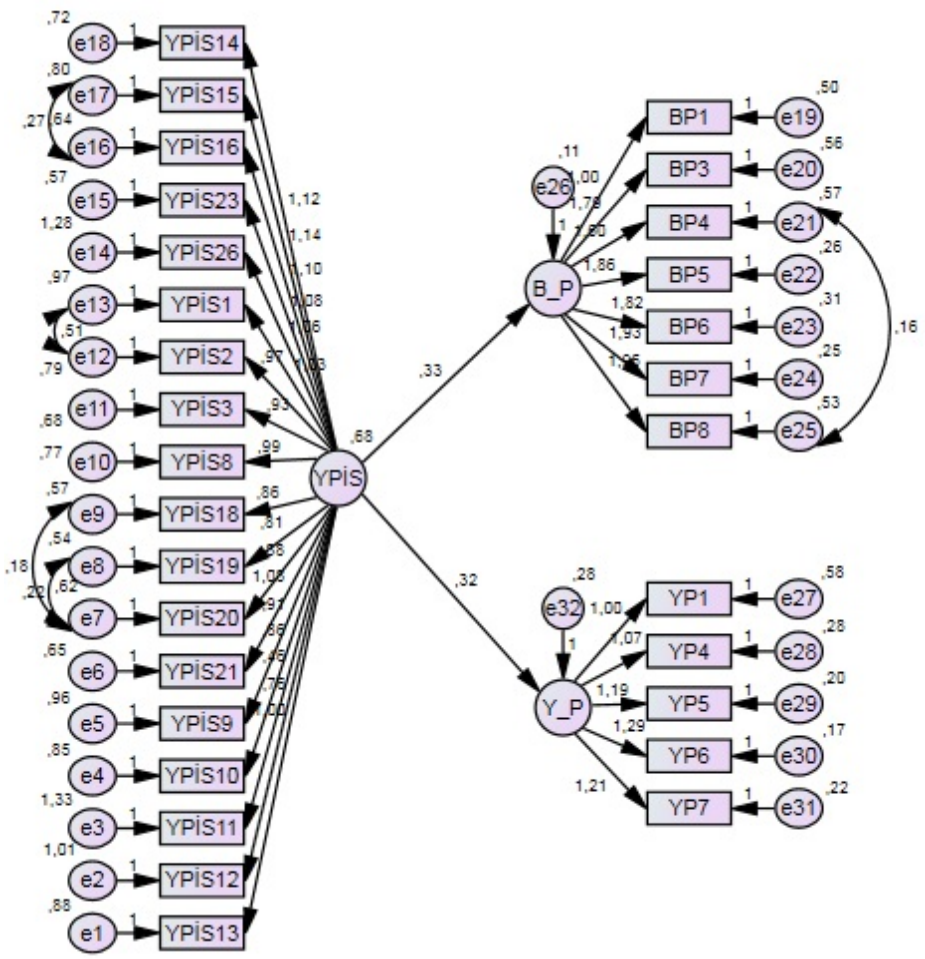

YPİS= Yüksek Performanslı İş Sistemleri; B_P: Bağlamsal Performans; Y_P: Yaratıcı Performans

Şekil 2: $H_{l}$ hipotezi için Yapısal Eşitlik Modeli

Şekil 2 incelendiğinde, yüksek performanslı iş sistemlerinin bağlamsal $(\beta=0,33 ; p<0,05)$ ve yaratıcı performans $(\beta=0,32 ; p<0,05)$ üzerindeki etkisinin pozitif yönlü ve anlamlı olduğu görülmüştür. Bu bulgulara dayanarak $\mathbf{H}_{\mathbf{1}}\left(\mathbf{H}_{1 \mathrm{a}}\right.$ ve $\left.\mathrm{H}_{1 \mathrm{~b}}\right)$ hipotezi desteklenmiştir.

Araştırmanın $\mathrm{H}_{2}$ hipotezini test etmek amacıyla oluşturulan yapısal eşitlik modeli Şekil 3'de gösterilmiştir. Söz konusu modelin uyum değerleri $\mathrm{X} 2 / \mathrm{df}=3,147$; GFI $=0,863$; CFI $=0,888$; RMSEA $=0,083$ olarak gerçekleşmiştir. Şekil 3'deki bulgulardan hareketle, yüksek performanslı iş sistemlerinin işe tutkunluk üzerindeki etkisinin $(\beta=0,60 ; p<0,05)$ pozitif yönlü ve anlamlı olduğu görülmüştür. Bu bulgulara dayanarak $\mathbf{H}_{2}$ hipotezi desteklenmiştir. 
Yüksek Performanslı İş Sistemlerinin Çalışan Performansı Üzerindeki Etkisinde Işse Tutkunluğun Aracılık Rolü

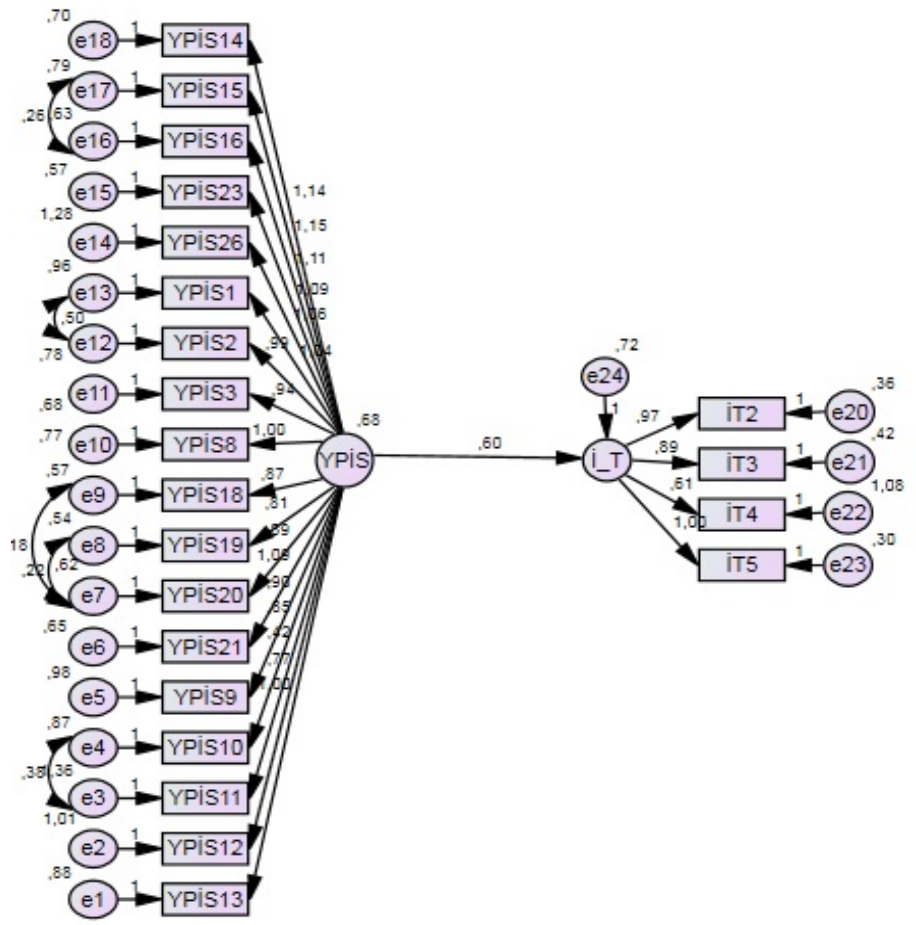

YPİS= Yüksek Performanslı İş Sistemleri; İ_T: İşe Tutkunluk

Şekil 3: $\mathrm{H}_{2}$ hipotezi için Yapısal Eşitlik Modeli

Araştırmanın $\mathrm{H}_{3}$ hipotezini test etmek amacıyla oluşturulan yapısal eşitlik modeli Şekil 4'de gösterilmiştir. Söz konusu modelin uyum değerleri $\mathrm{X}^{2} / \mathrm{df}=3,801 ; \mathrm{GFI}=0,850 ; \mathrm{CFI}=0,905 ; \mathrm{RMSEA}=0,095$ olarak gerçekleşmiştir. Şekil 4'deki bulgulardan hareketle, işe tutkunluğun bağlamsal performans $(\beta=0,73 ; p<0,05)$ ve yaratıcı performans $(\beta=0,64 ; p<0,05)$ üzerindeki etkisinin pozitif yönlü ve anlamlı olduğu saptanmıştır. Bu bulgulara dayanarak $\mathbf{H}_{\mathbf{3}}\left(\mathbf{H}_{\mathbf{3}}\right.$ ve $\mathrm{H}_{3 \mathrm{~b}}$ ) hipotezi desteklenmiştir. 


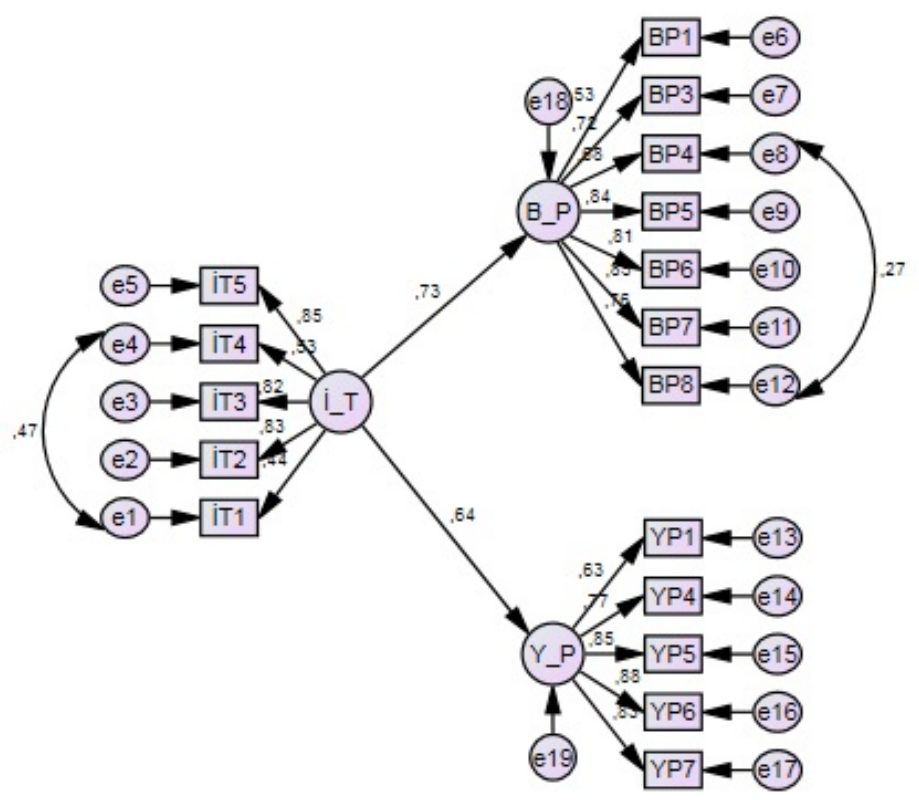

İT: İşe Tutkunluk; B_P: Bağlamsal Performans; Y_P: Yaratıcı Performans

Şekil 4: $H_{3}$ hipotezi için Yapısal Eşitlik Modeli

Araştırmanın diğer bir hipotezi üzerinden aracılık etkisini ölçümlemek için Baron ve Kenny (1986: 1176) tarafından öne sürülen yaklaşım izlenmiştir. Buna göre aracı değişken etkisini belirlemek üzere dört temel koşulun sağlanması gerekmektedir (Baron ve Kenny, 1986: 1176; Karagöz, 2016: 954; Gürbüz, 2019: 52):

$\checkmark$ Bağımsız değişkenin bağımlı değişken üzerinde anlamlı etkisi olmalıdır.

$\checkmark$ Bağımsız değişkenin aracı değişken üzerinde anlamlı etkisi olmalıdır.

$\checkmark$ Aracı değişkenin bağımlı değişken üzerinde anlamlı etkisi olmalıdır.

$\checkmark$ Aracı değişken bağımsız değişkenle birlikte modele dahil edildiğinde, bağımsız değişkenin bağımlı değişken üzerindeki etkisi azalırken, aracı değişkenin bağımlı değişken üzerindeki etkisi anlamlı olmalıdır. Diğer bir ifadeyle başlangıçta var olan etkinin tamamen ortadan kalkması (tam aracı etki) ya da azalması (k1smi aracı etki) gerekmektedir.

Baron ve Kenny (1986: 1176)'e göre değişkenler arasında bir aracılık etkisinden söz edebilmek için yukarıda belirtilen koşulların tümünün sağlanması gerekmektedir. Birinin bile sağlanmaması durumunda aracılık etkisinden söz edilemeyecektir (Gürbüz, 2019: 52). Bu kapsamda araştırmanın ilk üç hipotezine yönelik sonuçlar, Baron ve Kenny (1986: 1176) yaklaşımında öne sürülen koşulların desteklendiğini ortaya koymuştur. Dolayısıyla araştırmanın $\mathrm{H}_{4}$ 
Yüksek Performanslı İş Sistemlerinin Çalışan Performansı Üzerindeki Etkisinde İşe Tutkunluğun Aracıllk Rolü

hipotezini test etmek üzere yapısal eşitlik modellemesinden yararlanılmış ve elde edilen sonuçlar aşağıdaki Şekil 5'de sunulmuştur.

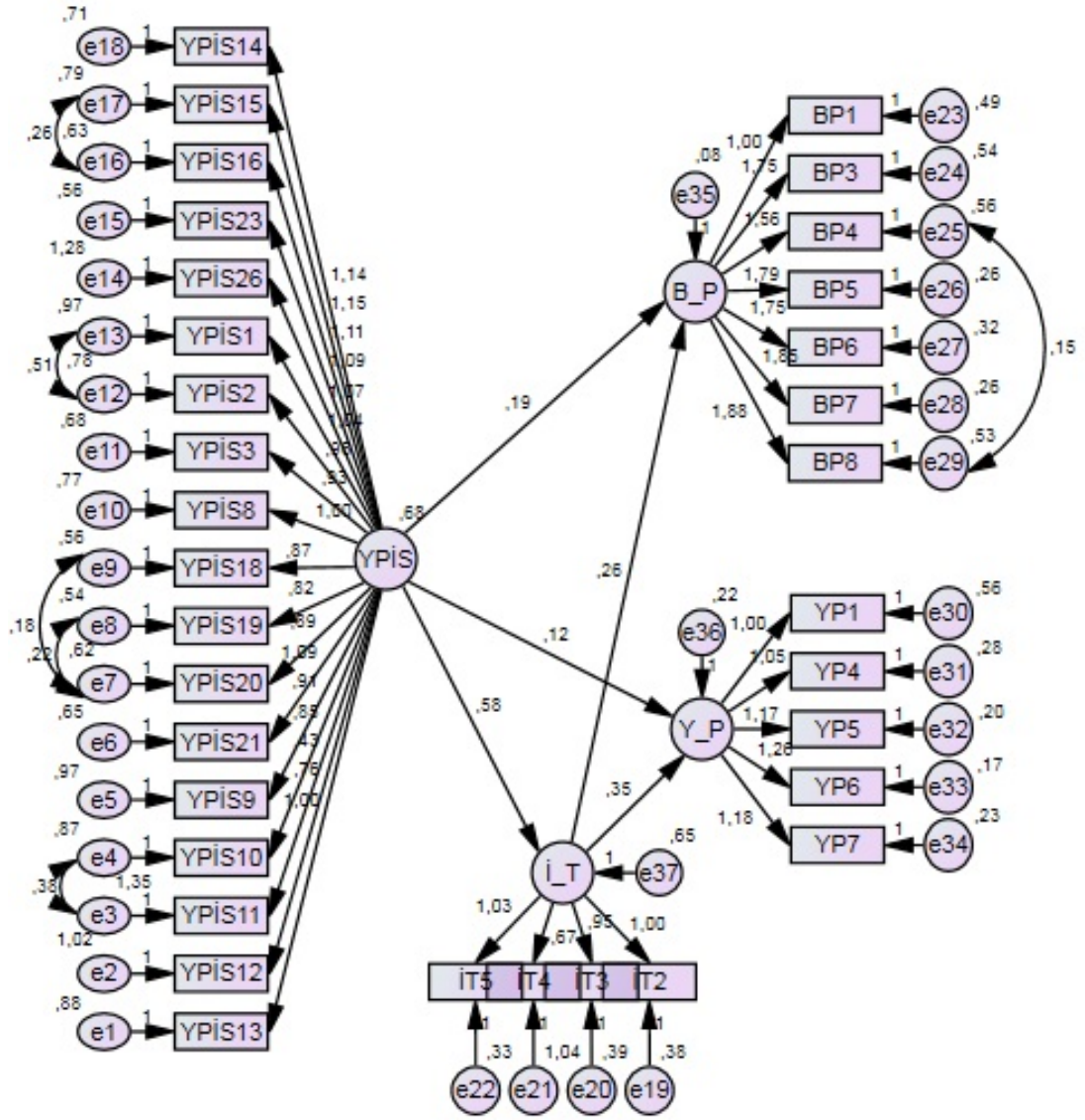

YPİS= Yüksek Performanslı İş Sistemleri; İ_T: İşe Tutkunluk; B_P: Bağlamsal Performans; Y_P: Yaratıcı Performans

Şekil 5: Aracılık Etki Analizi İçin Yapısal Eşitlik Modeli

Aracılık etkisini belirlemek üzere kurulan modelin uyum değerleri $\mathrm{X}^{2} / \mathrm{df}=2,551 ; \mathrm{GFI}=0,802 ; \mathrm{CFI}=0,880$; RMSEA $=0,070$ olarak gerçekleşmiştir. Şekil 5'deki sonuçlara göre bağımsız değişken yüksek performanslı iş sistemleri ve aracı değişken işe tutkunluk modele dahil edildiğinde, bağımsız değişken yüksek performanslı iş sistemlerinin bağımlı değişkenler olan bağlamsal performans $(\beta=0,33$ 'den $\beta=0,19$ olarak azalmıştır) ve yaratıcı performans ( $\beta=0,32$ 'den $\beta=0,12$ olarak azalmıştır) üzerindeki etkisi azalmış ve aracı değişken olan işe tutkunluğun bağımlı değişkenleri oluşturan bağlamsal ve yaratıcı performans üzerindeki etkisi anlamlı $(\mathrm{p}<0,05)$ çıkmıştır. Bu bulgular ışığında yüksek performanslı iş sistemlerinin bağlamsal ve yaratıcı performans üzerindeki 
etkisinde işe tutkunluğu kısmi aracılık etkisi olduğu saptanmıştır. Dolayısıyla $\mathbf{H}_{4}$ $\left(\mathbf{H}_{4 a}\right.$ ve $\left.\mathbf{H}_{4 b}\right)$ hipotezi kısmen desteklenmiştir.

\section{Sonuç}

Yüksek performanslı iş sistemlerinin çalışan performansı üzerindeki etkisinde işe tutkunluğun aracılık rolünü araştıran bu çalışmanın kurgusu, bağlamsal ve yaratıcı performans göstermesi istenen çalışanların işe tutkunluklarının olmasına bağlı olarak örgütlerin yüksek performanslı iş sistemlerini sağlaması ile olabileceğine dayanmaktadır.

Araştırma kapsamında ilk olarak yüksek performanslı iş sistemlerinin çalışan performansı üzerinde etkisi incelenmiştir. Çalışan performansının genel olarak bağlamsal ve görev performansına bağlandığı bazı çalışmalardan (ZoghbiManrique-de-Lara ve Ting-Ding, 2017: 77-93; Befort ve Hattrup, 2003: 17-32) ve tek boyutlu iş performansı olarak ele alan çalışmalardan (Karatepe, 2013: 132140) farklı olarak bu araştırmada, çalışan performansı bağlamsal performansın yanında çalışanların isle ilgili görevleri yerine getirirken yarattı̆̆ 1 yeni fikirlerin ve yeni davranışların miktarını gösteren yaratıcı performans açısından incelenmiştir. Araştırma sonuçlarına göre yüksek performanslı iş sistemleri bağlamsal performansı $(\beta=0,33)$ ve yaratıcı performansı $(\beta=0,32)$ anlamlı ve pozitif yönde etkilemektedir. İnsan kaynakları yönetim sistemini daha çok operasyonel düzeyde çözüm bulmaya ve örgütün rekabet stratejisinin odağına yerleştiren yüksek performanslı iş sistemlerinin çalışanların bağlamsal ve yaratıcı performanslarını etkilemesi sonucu, bu bağlamda beklenen bir sonuç olarak değerlendirilebilir. Araştırma sonuçları konuyla ilgili yapılan önceki çalışmalarla (Tabiu ve Nura, 2013: 247-260; Muchhal, 2014: 55-61; Manzoor, 2016: 354-363) benzer sonuçlar göstermiştir. Diğer taraftan yüksek performanslı iş sistemleri bağlamında iş analizi çalışmalarının insan kaynakları açısından kritik öneme sahip olduğu söylenebilir (Bkz. Tablo 5). İnsan kaynakları sistemi kapsamındaki çalışmaların kalbi ve çıkış noktası olan iş analizi çalışmalarının, yüksek performansl 1 iş sistemlerinin uygulanmasında önemi büyüktür. Eğitim-geliştirme çalışmaları ve kararlara katılım da yine çalışanlar tarafından yüksek performanslı iş sistemlerinin uygulanmasındaki önemli göstergeler olarak değerlendirilmiştir. $\mathrm{Bu}$ bağlamda yüksek performans göstermek isteyen günümüz iş dünyasındaki örgütlerin iş analizi, eğitim-geliştirme ve kararlara katılım üzerinde durması gerekmektedir.

Araştırmada ikinci olarak yüksek performanslı iş sistemlerinin çalışanların işe tutkunlukları üzerindeki etkisi incelenmiştir. Araştırma sonuçlarına göre yüksek performanslı iş sistemleri çalışanların işe tutkunluklarını $(\beta=0,60)$ pozitif yönlü ve güçlü bir düzeyde etkilemektedir. Bu sonuç konu üzerinde yapılan önceki çalışmalarla (Combs vd., 2006: 501-528; Alyzoud, 2018: 251-256; Suan ve Nasurdin, 2014: 245-260; Karatepe ve Olugbade, 2016: 2350-2371) benzerlik göstermiştir. İşe tutkunluklarını sağlayan güçlü bir öncül olarak yüksek performanslı iş sistemleri, çalışanların örgüt açısından önemli bir değer oldukları 
Yüksek Performanslı İşS Sistemlerinin Çalışan Performansı Üzerindeki Etkisinde İșe Tutkunluğun Aracıllk Rolü

yönündeki algılarının belirleyicisi olarak değerlendirilebilir. Örgütlerin yüksek performanslı iş sistemleri üzerinden çalı̧̧anlarının kurumsal ve bireysel gelişimine destek vermeleri, gösterecekleri performansı da etkilemektedir. Nitekim araştırma bulguları çalışanların işe tutkun olmaları ile bağlamsal $(\beta=0,73)$ ve yaratıcı performansları $(\beta=0,64)$ arasında da pozitif yönde güçlü ve ve anlamlı bir ilişki olduğunu göstermiştir. İșe tutkunlukları olan çalışanları bağlamsal performanslarını yaratıcı performanslarına oranla daha yüksek düzeyde ortaya koymaktadır. Bakker ve Bal (2010: 189-206), Bakker ve diğerleri (2012: 555-564) ve Song ve diğerleri (2018: 249-271) yaptıkları çalışmalar sonucunda da işe tutkunluğun çalışan performansını artırdığı yönünde sonuçlar elde etmişlerdir.

Araştırmanın son bulgusu ise, işe tutkunluğun aracılık etkisi ile ilgilidir. Çalışmanın temel kurgusunu oluşturan yüksek performanslı iş sistemlerinin çalışanların bağlamsal ve yaratıcı performansını etkilemede işe tutkunluğun bir aracılık edip etmediği araştırılmıştır. Baron ve Kenny (1986: 1176) öne sürdüğü aracılık etkisini araştırmaya yönelik koşullar sağlandıktan sonra oluşturulan yapısal eşitlik modellemesine göre, yüksek performanslı iş sistemlerinin çalışanların bağlamsal ve yaratıcı performansları üzerindeki etkisinde işe tutkunluğun kısmi arac1lık etkisi olduğu tespit edilmiştir. İşe tutkunluğun aracilık etkisini araştıran çalışmaların (Yalabik vd., 2013: 2799-2823; Li vd., 2012: 10591066; Karatepe, 2013: 132-140; Karatepe ve Olugbade, 2016: 2350-2371) tümünde aracılık etki kısmi ya da tam olarak belirlenmiştir. Bu çalışma sonucu da işe tutkunluğun yüksek performanslı iş sistemlerinin çalışan performansı üzerindeki etkisinde kısmi aracılık etkisi gösterdiğini ortaya koymuştur.

Bulgular genel olarak değerlendirildiğinde, örgütlerin yüksek performanslı iş sistemlerinin uygulanmasında özellikle iş analizi, eğitim-geliştirme ve kararlara katılıma önem vermeleri beklenmelidir. İşe tutkunluk çalışanların kendilerinden beklenen örgüt içi yapıcı ve olumlu davranışlarında önemli bir etki yaratmaktadır. Ayrıca çalışanların bağlamsal ve yaratıcı performans göstermelerinde yüksek performanslı iş sistemleri ve işe tutkun olmaları da yine önemli belirleyiciler arasındadır.

Her çalışmada olduğu gibi bu çalışmanın da bazı kısıtları söz konusudur. Öncelikle çalışmanın hizmet işletmeleri olarak belli bir alanı kapsaması ve sadece tek bir nicel yöntem üzerinden anketlerle verilerin toplanması, çalışmanın sonuçlarının genellenmesinde kısıtlayıcı bir etki yaratmıştır. Çalışmaların farklı iş kolları açısından yapılarak karşılaştırılması literatüre katkı sağlayacaktır. Ayrıca çalışmanın örneklemi kapsamında yüksek performanslı iş sistemlerinin tüm boyutlarının çalışan performansı üzerindeki etkisinin izlenememesi de, sonuçlar açısından anlamlı bir kısıt olarak değerlendirilebilir. Çok boyutlu bir değişken olarak yüksek performanslı iş sistemlerinin uygulandığı büyük ölçekli kurumsal örgütlerin araştırılması, bu bağlamda daha sağlıklı sonuçlar verebilir. 


\section{Kaynaklar}

Alzyoud, A.Y. (2018), The Influence of Human Resource Management Practices on Employee Work Engagement, Foundations of Management, 10(1): 251-256.

Armstrong, M. (2009), Armstrong's Handbook of Human Resource Management Practice, (11th Edition), UK: Kogan Page.

Baron, R.M. ve Kenny, D.A. (1986), The Moderator-Mediator Variable Distinction in Social Psychological Research: Conceptual, Strategic and Statistical Considerations, Journal of Personality and Psychology, 51(6): 173-182.

Bakker, A.B., Demerouti, E. ve Lieke, L. (2012), Work Engagement, Performance, and Active Learning: The Role of Conscientiousness, Journal of Vocational Behavior, 80(2): 555-564.

Bakker, A.B., Albrecht, S. L. ve Leiter, M.P. (2011), Key Questions Regarding Work Engagement, European Journal of Work and Organizational Psychology, 20(1): 4-28.

Bakker, A.B. ve Bal, M.P. (2010), Weekly Work Engagement and Performance: A Study Among Starting Teachers, Journal of Occupational and Organizational Psychology, 83(1): 189-206.

Befort, N. ve Hattrup, K. (2003), Valuing Task and Contextual Performance: Experience, Job Roles, and Ratings of the Importance of Job Behaviors, Applied Human Resources Management Research, 8(1): 17-32.

Berg, P. (1999), The Effects of High Performance Work Practices on Job Satisfaction in The United States Steel Industry, Industrial Relations, 54(1): 111-135.

Borman, W.C. ve Motowidlo, S.J. (1997), Task Performance and Contextual Performance: The Meaning for Personnel Selection Research, Human Performance, 10(2): 99-109.

Combs, J., Liu, Y., Hall, A. ve Ketchen, D. (2006), How Much Do HighPerformance Work Practices Matter? A Meta-Analysis of Their Effects on Organizational Performance, Personnel Psychology, 59(3): 501-528.

Dessler, G. (2013), Human Resources Management, (13th Edition), USA: Pearson Education Limited.

Evans, W.R. ve Davis, W.D. (2005), High-Performance Work Systems and Organizational Performance: The Mediating Role of Internal Social Structure, Journal of Management, 31(5): 758-775.

Guthrie, J. P., Flood, P. C., Liu, W. ve Maccurtain, S. (2009), High Performance Work Systems in Ireland: Human Resource and Organizational Outcomes, The International Journal of Human Resource Management, 20(1): 112-125.

Gürbüz, S. (2019), Aracı, Düzenleyici ve Durumsal Etki Analizleri, Ankara: Seçkin Yayıncılık. 
Yüksek Performanslı İş Sistemlerinin Çalışan Performansı Üzerindeki Etkisinde İşe Tutkunluğun Aracıllk Rolü

Harari, M.B., Reaves, A.C. ve Viswesvaran, C. (2016), Creative and Innovative Performance: A Meta-Analysis of Relationships with Task, Citizenship, and Counterproductive Job Performance Dimensions, European Journal of Work and Organizational Psychology, 25(4): 495-511.

Hartog, D.N. ve Verburg, R.M. (2004), High Performance Work Systems, Organizational Culture and Firm Effectiveness, Human Resource Management Journal, 14(1): 55-78.

Huselid, M.A. (1995), The Impact of Human Resource Management Practices on Turnover, Productivity, and Corporate Financial Performance, Academy of Management Journal, 38(3): 635-672.

Huselid, M.A. ve Becker, B.E. (1996), Methodological Issues in Cross-Sectional and Panel Estimates of the Human Resource-Firm Performance Link, Industrial Relations: A Journal of Economy and Society, 35(3): 400422.

Jung, H.S. ve Yoon, H.H. (2016), What Does Work Meaning to Hospitality Employees? The Effects of Meaningful Work on Employees' Organizational Commitment: The Mediating Role of Job Engagement, International Journal of Hospitality Management, 53: 59-68.

Karagöz, Y. (2016), SPSS ve AMOS 23 Uygulamalı İstatistiksel Analizler, Ankara: Nobel Yayıncilik.

Karatepe, O.M. (2013), High-Performance Work Practices and Hotel Employee Performance: The Mediation of Work Engagement, International Journal of Hospitality Management, 32: 132-140.

Karatepe, O.M. ve Olugbade, O.A. (2016), The Mediating Role of Work Engagement in the Relationship Between High-Performance Work Practices and Job Outcomes of Employees in Nigeria, International Journal of Contemporary Hospitality Management, 28(10): 2350-2371.

Kehoe, R.R. ve Wright, P.M. (2013), The Impact of High-Performance Human Resource Practices on Employees' Attitudes and Behaviors, Journal of Management, 39(2): 366-391.

Kroon, B., Van de Voorde, K. ve Van Veldhoven, M. J. P. M. (2009), CrossLevel Effects of High-Performance Work Practices on Burnout: Two Counteracting Mediating Mechanisms Compared, Personnel Review, 38(5): 509-525.

Li, X., Sanders, K. ve Frenkel, S. (2012), How Leader-Member Exchange, Work Engagement and HRM Consistency Explain Chinese Luxury Hotel Employees'Job Performance, International Journal of Hospitality Management, 31(4): 1059-1066.

Luna-Arocas, R. ve Camps, J. (2007), A Model of High Performance Work Practices and Turnover Intentions, Personnel Review, 37(1): 26-46.

Manzoor, F. (2016), Evaluating The Role of Human Resource Management (Hrm) Practices on Job Performance: An Application of Employee 
Empowerment as Moderator, City University Research Journal, 6(2): 354363.

Meydan, C.H. ve Şeşen, H. (2011), Yapısal Eşitlik Modellemesi Amos Uygulamalarl, Ankara: Detay Yayıncilık.

Muchhal, D.S. (2014), HR Practices and Job Performance, IOSR Journal of Humanities and Social Science, 19(4): 55-61.

Patel, P., Messersmith, J. ve Lepak, D. (2013), Walkıng the Tightrope: An Assessment of the Relationship Between High-Performance Work Systems and Organizational Ambidexterity, The Academy of Management Journal, 56(5): 1420-1442.

Posthuma, R.A., Campion, M.C., Masimova, M. ve Campion, M.A. (2013), A High Performance Work Practices Taxonomy: Integrating the Literature and Directing Future Research, Journal of Management, 39(5): 11841220 .

Saruhan, S.C. ve Özdemirci, A. (2011), Bilim, Felsefe ve Metedoloji, İstanbul: Beta Yayıncilık.

Schaufeli, B.W., Bakker, A.B. ve Salanova, M. (2006), The Measurement of Work Engagement with A Short Questionnaire, Educational and Psychological Measurement, 66(4): 701-716.

Schaufeli, W.B., Salanova, M., Gonzalez-Roma, V. ve Bakker, A.B. (2002), Burnout and Engagement in University Students, Journal of CrossCultural Psychology, 33(5): 464-481.

Sipahi, E., Yurtkoru, E.S. ve Çinko, M. (2008), Sosyal Bilimlerde SPSS'le Veri Analizi (2. Baskı), İstanbul: Beta Yayınları.

Shih, H.A., Chiang, Y.H. ve Hsu, C.C. (2006), Can High Performance Work Systems Really Lead to Better Performance? International Journal of Manpower, 27(8): 741-763.

Song, J.H., Chai, D.S., Kim, J. ve Bae, S.H. (2018), Job Performance in the Learning Organization: The Mediating Impacts of Self-Efficacy and Work Engagement, Performance Improvement Quarterly, 30(4): 249-271.

Sturm, T. (2007), High Commitment HRM Organizations - A Case Study, Germany: Grin Verlag.

Suan, C.L. ve Nasurdin, A.M. (2014), An Empirical Investigation into the Influence of Human Resource Management Practices on Work Engagement: The Case of Customer-Contact Employees in Malaysia, International Journal of Culture, Tourism and Hospitality Research, 8: 345-360.

Tabiu, A. ve Nura, A.A. (2013), Assessing the Effects of Human Resource Management (Hrm) Practices on Employee Job Performance: A Study of Usmanu Danfodiyo University Sokoto, Journal of Business Studies Quarterly, 5(2): 247-260. 
Yüksek Performanslı İş Sistemlerinin Çalışan Performansı Üzerindeki Etkisinde İşe Tutkunluğun Aracıllk Rolü

Varma, A., Beatty, R.W., Schneier, C.E. ve ULRICH, D.O. (1999), High Performance Work Systems: Exciting Discovery or Passing Fad? Human Resource Planning, 22(1), 26-37.

Wang, G. ve Netemeyer, R.G. (2004), Salesperson Creative Performance: Conceptualization, Measurement, and Nomological Validity, Journal of Business Research, 57(8): 805-812.

Wang, S., YI, X., Lawler, J. ve Zhang, M. (2011), Efficacy of High-Performance Work Practices in Chinese Companies, The International Journal of Human Resource Management, 22(11): 2419-2441.

Wei, Y.C., Han, T.S. ve Hsu, I. C. (2010), High-Performance HR Practices and OCB: A Cross-Level Investigation of A Causal Path, The International Journal of Human Resource Management, 21(10): 1631-1648.

Whitener, E.M. (2001), Do "High Commitment" Human Resource Practices Affect Employee Commitment? A Cross-Level Analysis Using Hierarchical Linear Modeling, Journal of Management, 27: 515-535.

Wickramasinghe, V. ve Liyanage, S. (2013), Effects of High Performance Work Practices on Job Performance in Project-Based Organizations, Project Management Journal, 44(3): 64-77.

Wu, P. C. ve Chaturvedi, S. (2009), The Role of Procedural Justice and Power Distance in the Relationship Between High Performance Work Systems and Employee Attitudes: A Multilevel Perspective, Journal of Management, 35(5): 1228-1247.

Yalabik, Z.Y., Popaitoon, P., Chowne, J.A. ve Rayton, B.A. (2013), Work Engagement as a Mediator Between Employee Attitudes and Outcomes, The International Journal of Human Resource Management, 24(14): 2799-2823.

Yeh, M.C. (2013), Tourism Involvement, Work Engagement and Job Satisfaction Among Frontline Hotel Employees, Annals of Tourism Research, 42: 214239.

Zacharatos, A., Barling, J. ve Iverson, R.D. (2005), High-Performance Work Systems and Occupational Safety, Journal of Applied Psychology, 90(1): 77-93.

Zoghbi-Manrique-De-Lara, P. ve Ting-Ding, J.M. (2017), Task and Contextual Performance as Reactions of Hotel Staff to Labor Outsourcing: The Role of Procedural Justice, Journal of Hospitality and Tourism Management, 33: 51-61. 